\title{
4-THIAZOLIDINONE-BASED DERIVATIVES RESCUE TNA $\alpha$-INHIBITED OSTEOBLAST DIFFERENTIATION IN MOUSE MESENCHYMAL PRECURSOR CELLS
}

\author{
Kh. V. MALYSHEVA ${ }^{1,2,3}$, N. S. FINIUK ${ }^{1}$, O. K. PAVLENKO ${ }^{4}$ D. Ya. HAVRYLYUK ${ }^{5}$, \\ R. B. LESYK ${ }^{5}$, R. S. STOIKA ${ }^{1}$, O. G. KORCHYNSKYI $I^{1,3}$ \\ ${ }^{1}$ Institute of Cell Biology, NAS of Ukraine, Lviv; \\ ${ }^{2}$ Insitute of Animal Biology, NAAS of Ukraine, Lviv; \\ ${ }^{3}$ Centre for Innovative Research in Medical and Natural Sciences, \\ Medical Faculty, Rzeszow University, Poland; \\ ${ }^{4}$ Ivan Franko National University of Lviv, Ukraine; \\ ${ }^{5}$ Danylo Halytsky Lviv National Medical University, Ukraine; \\ e-mail:olexkor@hotmail.com
}

Rheumatoid arthritis (RA) is an autoimmune inflammatory disease of yet unknown etiology. Tumor necrosis factor $\alpha(T N F \alpha)$ is recognized as a regulatory substance that plays a central role in $R A$ development and progression. On the other side, the bone morphogenetic protein (BMP) and Wnt signaling pathways are key mechanisms that induce and support cartilage and bone formation and maintenance. Previous studies showed that the pro-inflammatory cytokines TNFa and interleukin $1 \beta(I L-1 \beta)$ are central players in the inhibition of activity of skeletogenesis. The aim of this study was to evaluate the anti-inflammatory activity of novel 4-thiazolidinone-based derivatives towards TNFQ-induced pro-inflammatory effects during bone formation. We performed in vitro evaluation of functional effects of 4-thiazolidinones denoted as Les-4368, Les-4370, Les-3882 and Les-3288 that were used in different doses (0.02, 0.1, 0.3 and 1.0 $\mu \mathrm{M}$ ) on the TNFa-mediated inhibition of the BMP-induced osteoblast differentiation in mouse mesenchymal precursor (stem) cells of C2C12 line. Treatment of these cells with TNFa completely inhibited their myogenic differentiation, as well as strongly inhibited the BMP-induced osteogenesis. Strikingly, the treatment of C2C12 cells with Les-4368 and Les-3882 rescued the osteoblast differentiation from negative control of TNF $\alpha$, and, moreover, converted this cytokine from the inhibitor of osteogenesis into its stimulator. Western-blot analysis of Inhibitory $\kappa B \alpha(I-\kappa B \alpha)$ degradation was used to elucidate a mechanism of the anti-inflammatory effects. Les-3882 was more active, and it stimulated osteoblast differentiation at low dose $(0.1 \mu \mathrm{M})$, presumably, via modulation of the NF- $\kappa B$ signaling pathway.

Key words: osteoblast differentiation, mouse mesenchymal precursor cells, inflammation, bone morphogenetic proteins, 4-thiazolidinone derivatives.

$\mathrm{R}$ heumatoid arthritis (RA) is a widespread inflammatory autoimmune disorder associated with a progressive disability and multiple systemic complications that can even lead to early death of patients [1]. Synovial inflammation and joint swelling alone or combined with autoantibody production (rheumatoid factor and anti-citrullinated peptide antibodies), cartilage and bone damage, as well as multiple adverse systemic effects are common symptoms of RA [2]. The actual etiology of the disease is still a mystery and many details of RA pathogenesis are poorly understood [3].

Different cytokines are known to control skeletal homeostasis as well as functions of the immune system that are mis-regulated in RA pathogenesis [4]. The disturbed balance of pro-inflammatory versus anti-inflammatory stimuli contributes to RA triggering. Multiple cytokines are involved in regulation of tissue and cellular functions during phases of RA pathophysiology via promoting autoimmunity, maintaining chronic inflammatory synovitis, and leading to a destruction of the adjacent joint tissues. Clinical studies performed with TNF blockers, predominantly with its soluble receptor, led to a successful use of these blockers in patients' treatment and confirmed a key role of this pro-inflammatory cytokine in RA pathogenesis, as well as in other inflammatory disorders $[5,6]$. 
The inflammation is considered to be a defensive reaction of organism characterized by the coordinated activation or inhibition of various signaling pathways that control expression of either pro- and anti-inflammatory mediators. TNF $\alpha$, IL- $1 \beta, T-$ and B-cell receptors and pattern recognition Toll-like receptors are potent physiological inducers of key proinflammatory signaling pathway called the NF- $\kappa B$ (nuclear factor $\kappa$-light-chain-enhancer of activated $\mathrm{B}$ cells). Activation of NF- $\kappa \mathrm{B}$ signaling is important for expression of products of multiple pro-inflammatory genes, including cytokines, chemoattractant chemokines, and adhesion molecules [7, 8].

Several signaling pathways are mis-regulated in joints of the RA patients. The regulatory pathway of bone morphogenetic protein (BMP) and wingless (Wnt) are key signaling mechanisms involved in the induction and support of bone and cartilage formation and also important for skeleton maintenance. Although osteoblast differentiation is predominantly induced by the BMPs that belong to transforming growth factor $\beta$ (TGF- $\beta$ ) superfamily, the properly coordinated activation of Wnt pathway is also essential for bone formation induction, maintenance, remodeling and reparation via regulation of the osteoblast and osteoclast proliferation and differentiation. A commitment of mesenchymal precursors to the osteo- and chondrogenic lineages requires a precise coordination of BMP and Wnt signals. However, gene knockout studies and genetic analysis of bone diseases also identified the classical Wnt pathway as the master regulatory signaling in skeletal homeostasis [9-13].

Wnt/ $\beta$-catenin pathway is crucially important in bone due to its multiple important functions. Wnts inhibit chondrocyte and adipocyte differentiation, thus, repressing the alternative directions for differentiation of mesenchymal stem cells, and therefore promoting osteoblast growth and differentiation, increasing their mineralization activity and simultaneously blocking their apoptosis. Wnt ligands via $\beta$-catenin stabilization increase the ratio between the anti-receptor osteoprotegerin (OPG) and RANKL (receptor activating NF- $\kappa \mathrm{B}$ ligand), thus, repress the osteoclastogenesis. In a healthy skeleton, deposition and resorption of boned adjacent to joints are precisely balanced, while chronic inflammatory disorders such as RA lead to a disruption of such balance. TNF $\alpha$ produced by the inflammatory cells hampers osteoblast functions via the target genes of IL-6 and DKK-1. As a result repressed osteoblasts produce less of OPG, while bone resorption is enhanced by dumping of OPG/RANKL ratio that is a key factor controlling osteoclast activation and differentiation [13-16]. Therefore, pro-inflammatory cytokines massively block skeletogenic signaling pathways at the affected joints and also promote adjacent bone resorption, thus, causing bone erosions.

In spite of a high incidence of RA in the world (up to $1.8 \%$ of adult human population), yet there is no efficient cure of the RA. Several protocols, including a use of TNF and IL-6 blockers, were developed and widely used. These drugs can slow down or even stop RA development, or at least keep joint destruction minimal. Unfortunately, none of the existing drugs can reverse the joint damage and regenerate destroyed tissues. Thus, it is important to develop new highly effective therapeutics for RA and other autoimmune diseases.

4-Thiazolidinones are derivatives of thiazolidine with a carbonyl group at 4 -th position. This structure is a core for a series of synthetic pharmaceutical compounds displaying a wide spectrum of biological activities, such as antimicrobial, anticancer, anticonvulsant, anti-inflammatory and analgesic, antidiabetic, anti-parasitic, antiviral, including anti-HIV, anti-hyperlipidemic, antihypertensive, and monoamine oxidase inhibitors. Such diversity in the biological responses of 4-thiazolidinones has attracted attention of many researchers [17, 18].

In this study, we addressed the anti-inflammatory activity of novel 4-thiazolidinone-based derivatives towards $\mathrm{TNF} \alpha$-induced inflammatory processes during osteoblast differentiation in mouse mesenchymal precursor (stem) cells (MP/SC). We optionally have focused at the 4-thiazolidinone compounds that possess minimal cytotoxicity in order to prevent destructive side effects in the inflamed joint.

\section{Materials and Methods}

Materials. Synthesis and physicochemical data of the compounds used in this study were described previously: Les-3882 and Les-3288 [19], Les-4368 and Les-4370 [20, 21].

Immediately before use, 4-thiazolidinone derivatives were dissolved in the pure dimethyl sulfoxide (DMSO) at concentration $1 \mathrm{mM}$. The final concentration of the DMSO in the medium of cultured cells was not higher than $0.1 \%$. Subsequent dilutions of these compounds were performed in the Dulbecco's modified Eagle's medium (DMEM, Biowest, France). 
Cell culture and ligands. The studies were performed using the immortalized mouse mesenchymal precursor/stem cells of $\mathrm{C} 2 \mathrm{C} 12$ line. The cells were cultured in the DMEM containing 10\% fetal bovine serum (FBS, Biowest, France). The cells were grown in a $5 \% \mathrm{CO}_{2}$-containing atmosphere at $37{ }^{\circ} \mathrm{C}$ and $100 \%$ humidity. Culture medium was refreshed every 2-3 days. Before sub-cultivation, cells were washed with phosphate-buffered saline (PBS) that contained $137 \mathrm{mM} \mathrm{NaCl}, 2.7 \mathrm{mM} \mathrm{KCl}, 4.3 \mathrm{mM}$ $\mathrm{Na}_{2} \mathrm{HPO}_{4}$ and $1.4 \mathrm{mM} \mathrm{KH}_{2} \mathrm{PO}_{4}$ with pH 7.4. During osteoblast differentiation assays, $\mathrm{C} 2 \mathrm{C} 12$ cells in appropriate variants of the experiment were treated with $10 \mathrm{ng} / \mathrm{ml}$ of recombinant TNF $\alpha$ (R\&D Systems, Minneapolis, MN, USA).

Cell viability assay. MTT (3-(4,5-dimethylthiazol-2-yl)-2,5-diphenyltetrazolium bromide) assay was used for assessing cell metabolic activity. $\mathrm{C} 2 \mathrm{C} 12$ cells were grown for $24 \mathrm{~h}$ in 24 -well plates $(500 \mu \mathrm{l})$ at 30,000 cells per well. After that, cells were incubated for $72 \mathrm{~h}$ with various additions of the synthesized compounds (final concentration of $0.02 ; 0.01$; $0.5 ; 1.0 \mu \mathrm{M})$. Then, the MTT assay of viable cells was used in accordance with the manufacturer's recommendations (Sigma Aldrich, St. Louis, MS, USA). The reaction product was quantitatively determined by an Absorbance Reader BioTek EL*800 (BioTek Instruments, Inc., Winooski, VT, USA) at the wavelength of $620 \mathrm{~nm}$. The viability of the untreated cells was counted as $100 \%$.

Induction of osteoblast differentiation. C2C12 cells were induced to differentiate into osteoblasts by different BMPs, including BMP2 and BMP7. Cells were split at a density of $1.5 \times 10^{4}$ cells per $\mathrm{cm}^{2}$ in $24-$ well plates. Next day, the cells were transduced with a combination of adenoviral constructs encoding the recombinant $\mathrm{BMP} 2$ and $\mathrm{BMP} 7$ at the multiplicity of infection (MOI) even to 500 for each one construct [22] to induce a production of the BMP2/BMP7 heterodimers along with the appropriate homodimers. During osteogenesis assay, $\mathrm{C} 2 \mathrm{C} 12$ cells were cultured for 4 days in a differentiation-supporting medium supplemented with $50 \mu \mathrm{g} / \mathrm{ml}$ ascorbic acid. Plasmids encoding recombinant BMPs were purchased from Open Biosystems/GE Dharmacon, Lafayette, $\mathrm{CO}$, USA.

Alkaline phosphatase assay. The alkaline phosphatase activity produced by $\mathrm{C} 2 \mathrm{C} 12$ was analyzed spectrophotometrically using a $\pi$-nitrophenylphosphate ( $\pi$-NPP) as a substrate [23]. Four days after induction of osteogenesis, the cells were washed twice with $0.4 \mathrm{ml}$ of $1 \mathrm{X}$ PBS per well. Afterwards, cells were lysed in $0.2 \mathrm{ml}$ of alkaline phosphatase (ALP) lysis buffer $(10 \mathrm{mM}$ glycine, $100 \mu \mathrm{M} \mathrm{MgCl}_{2}, 10 \mu \mathrm{M} \mathrm{ZnCl}_{2}, 0.1 \%$ Triton X-100) per well and agitated gently for $5 \mathrm{~min}$. Then, $10 \mu \mathrm{l}$ aliquot of cell lysate was placed into a 96-well plate and ALP activity was revealed with $90 \mu \mathrm{l} /$ well of ALP assay buffer $(100 \mathrm{mM}$ glycine, $1 \mathrm{mM} \mathrm{MgCl}$, $100 \mu \mathrm{M} \mathrm{ZnCl}_{2}$ ) supplemented with $6 \mathrm{mM} \pi$-NPP (Pierce-Thermo Fisher Scientific, Grand Island, NY, USA.) [23]. Plates were agitated gently and incubated at room temperature until color developed. The absorption was measured at $405 \mathrm{~nm}$ (OD405) in a 96-well plate Absorbance Reader BioTek EL*800 (BioTek, Winooski, VT, USA). The level of expression of the enzyme is directly proportional to the intensity of mesenchymal precursor cells osteoblast differentiation.

Western-blot analysis. After cell treatment with the tested compound, cells were lysed and $20 \mu \mathrm{g}$ of total cellular protein per well was subjected to electrophoresis on $12 \%$ SDS/PAGE gel. Then, proteins were transferred onto a polyvinylidene difluoride (PVDF) membrane for immunoblot analysis, as described [24]. The anti-IкB $\alpha$ (Santa Cruz Biotechnology, Santa Cruz, CA, USA) antibodies were used at a 1:1,000 dilution: Equal protein loading of each lane was evaluated by the immunoblotting of the same membrane with anti- $\beta$-actin monoclonal mouse AC15 (1:5,000, Sigma Aldrich, St. Louis, MS, USA). Appropriate secondary peroxidase-labelled antibodies (Cell Signaling Technology, Beverly, MA, USA) were used at a dilution of 1:10,000.

Statistical analysis. All experiments were repeated twice, using three parallel wells in each variant. Results of spectrophotometric measurements of ALP activity are expressed as mean \pm standard deviation. Data were analyzed using GraphPad Prism 6 and Microsoft Office Excel programs. Statistical differences between experimental variants were assessed by Student's $t$-test. Appropriate $\mathrm{P}$ values were shown in graphs to demonstrate the significance of the results. Only differences with $P$-values lower than 0.05 were considered as significant.

\section{Results and Discussion}

As mentioned above, 4-thiazolidinone-based compounds possess a broad spectrum of the biological activities [18-21]. In a current study, we focused at the compounds possessing a capability of modu- 
lating osteoblast differentiation in mouse mesenchymal precursor cells and demonstrating minimal cytotoxicity in order to avoid of any destructive side effects in the targeted tissue.

Cell viability study of novel 4-thiazolidinone derivatives. The molecular design of new compounds based on commonly used modifying chemical groups is one of the most successful approached in drug development. 4-Thiazolidinone derivatives (Les-4368, Les-4370, Les-3882 and Les-3288) differing by the presence of specific functional groups and the position of these groups in the molecule structure were synthesized (Fig. 1).

Cytotoxic action of Les-4368, Les-4370, Les3882 , and Les-3288 towards MP/SC of C2C12 line used as an experimental model was studied. These compounds were added to the cultured medium at different concentrations $(0.02,0.1,0.5$ and $1.0 \mu \mathrm{M})$ for $72 \mathrm{~h}$. DMSO vehicle dissolved in DMEM at the same concentrations as the 4-thiazolidinone compounds was used as a negative control (Fig. 2). Les4368, Les-4370, Les-3882, and Les-3288 demonstrat-<smiles>CC(=O)Oc1cccc(N2C(=O)/C(=C/N3N=C(c4ccccc4)CC3c3ccccc3O)SC2=S)c1</smiles>

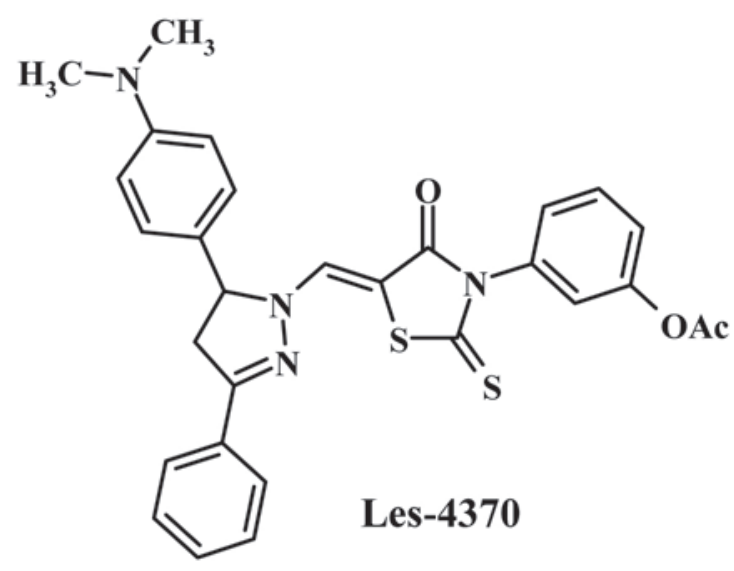

ed low toxicity for pre-osteoblastic $\mathrm{C} 2 \mathrm{C} 12$ cells at the used concentrations.

The anti-inflammatory activity of novel 4-thiazolidinone derivatives towards TNF $\alpha$-induced inhibition of the osteoblast differentiation. The main goal of our study was to evaluate the anti-inflammatory effects of Les-4368, Les-4370, Les-3882, and Les-3288 towards TNF $\alpha$-induced pro-inflammatory effects during osteoblast differentiation. We used the immortalized mouse MP/SC of $\mathrm{C} 2 \mathrm{C} 12$ line that are known as a useful tool to study differentiation of the myoblasts and osteoblasts. These cells can be induced by different BMPs, including BMP2 and BMP7, to differentiate efficiently into the early osteoblasts.

It was found that treatment of $\mathrm{C} 2 \mathrm{C} 12$ cells with $10 \mathrm{ng} / \mathrm{ml}$ of TNF $\alpha$ completely inhibited their myoblast differentiation (data not shown), and it also strongly inhibited BMP2/7-induced osteoblast differentiation (Fig. 3, control variant). We have tested which of the 4-thiazolidinone derivatives will show the anti-inflammatory effects. Les-4368, Les-4370, Les-3882, or Les-3288 were added to the cultured<smiles>COc1ccc(C2CC(c3ccc4ccccc4c3)=NN2C2=NC(=O)/C(=C3/C(=O)Nc4ccccc43)S2)cc1</smiles>

Les-3882

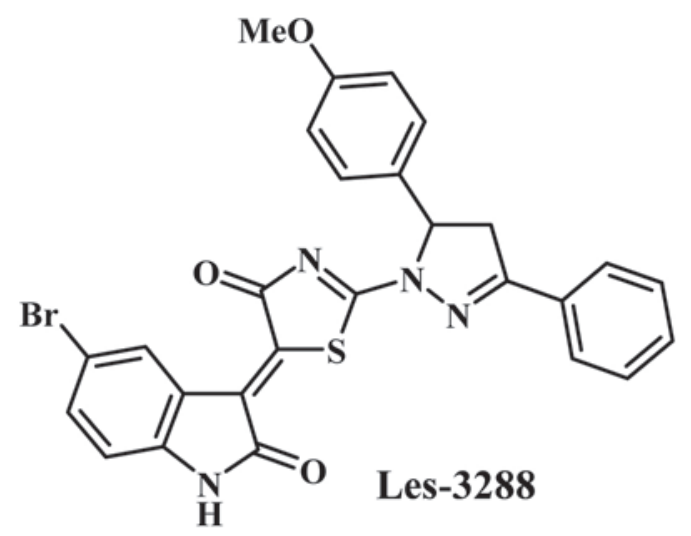

Fig. 1. Chemical structure of the 4-thiazolidinone-based derivatives - Les-4368, Les-4370, Les-3882 and Les3288 under study 


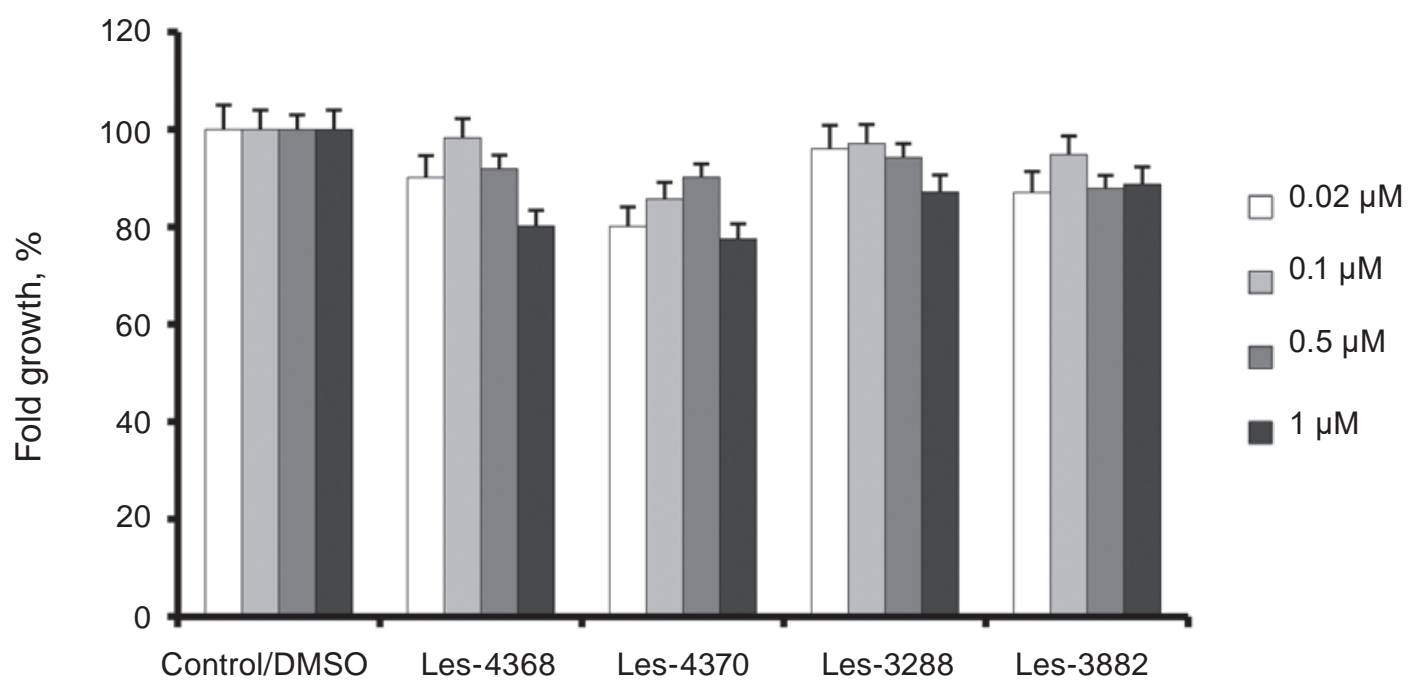

Fig. 2. 4-thiazolidinone derivatives at 0.02-1.0 $\mu$ M concentrations do not demonstrate a significant cytotoxicity towards mesenchymal C2C12 cells. MTT cell viability assay was performed with C2C12 cells treated with 0.02-1.0 $\mu M$ 4-thiazolidinone compounds. Data are presented as a percentage of alive cells in comparison to control cells treated with plain DMSO vehicle used at the same final concentration

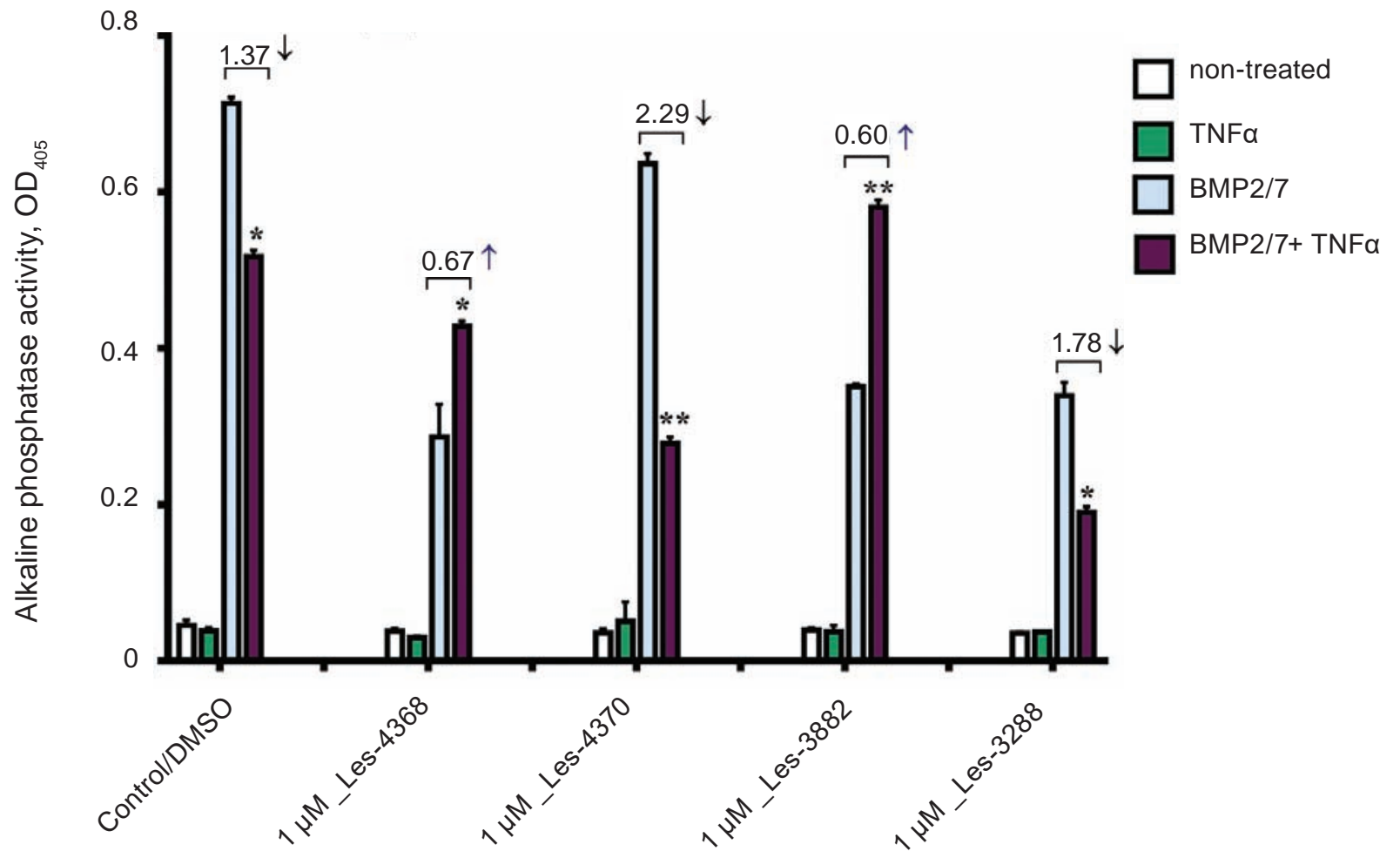

Fig. 3. 4-thiazolidinone derivatives Les-4368 and Les-3882 (1 $\mu \mathrm{M})$ rescue osteogenesis in C2C12 cells from negative control of the pro-inflammatory cytokine TNFa $(10 \mathrm{ng} / \mathrm{ml})$. Spectrophotometric measurement of the alkaline phosphatase activity in C2C12 cells induced to the osteoblast differentiation with the BMP2/7 and simultaneously treated with $10 \mathrm{ng} / \mathrm{ml} T N F \alpha$ and/or indicated 4-thiazolidinone compound. Significant differences are indicated, $* P<0.05$ and $* * P<0.01$ 


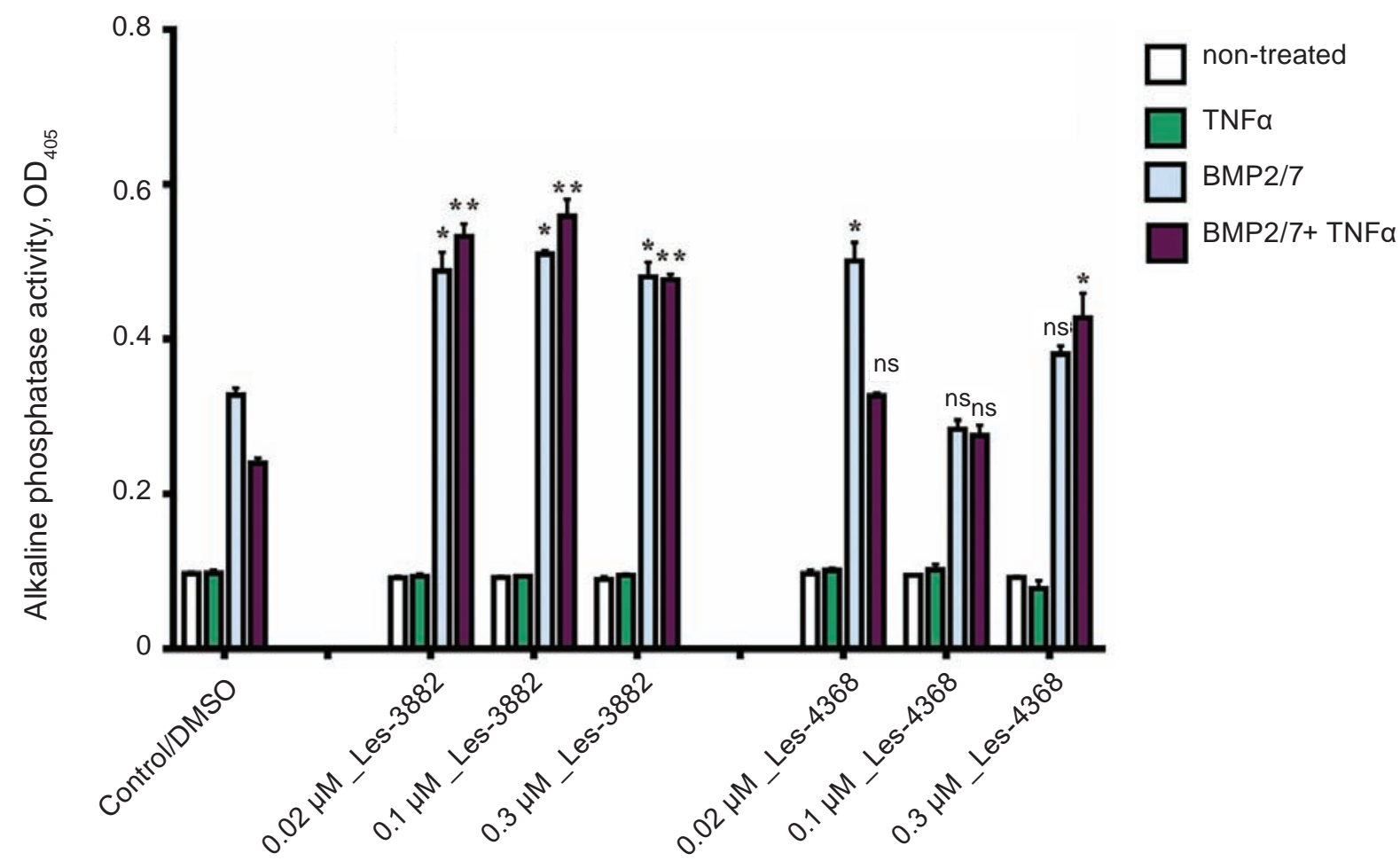

Fig. 4. 4-thiazolidinone derivative Les-3882 possesses the highest activity in rescuing osteogenesis in C2C12 cells from negative control of the pro-inflammatory cytokine TNFa $(10 \mathrm{ng} / \mathrm{ml})$. Spectrophotometric measurement of the alkaline phosphatase activity in C2C12 cells induced to the osteoblast differentiation with the $B M P 2 / 7$ and simultaneously treated with $10 \mathrm{ng} / \mathrm{ml} \mathrm{TNF \alpha}$ and/or indicated 4-thiazolidinone compounds (0.02$0.3 \mu \mathrm{M})$. Significant differences vs control values are indicated, $n s-$ non significant, $* P<0.05$ and $* * P<0.01$

medium in $1 \mu \mathrm{M}$ concentration 5-6 h after BMP2/7 induction of $\mathrm{C} 2 \mathrm{C} 12$ cells. DMSO vehicle dissolved in the DMEM at concentrations of $0.1 \%(\mathrm{v} / \mathrm{v})$ was used as a negative control. TNF $\alpha$ was added $1 \mathrm{~h}$ after the addition of compounds.

In case of using Les-4368 and Les-3882 for treatment of $\mathrm{C} 2 \mathrm{C} 12$ cells, they rescued the osteoblast differentiation due to negative control of TNF $\alpha$. Moreover, these compounds converted their action from the inhibition of osteoblast differentiation to its stimulation compared with a control. For confirmation of modulating osteoblast differentiation, spectrophotometric measurement of ALP activity that is a known marker of the osteoblast differentiation was used (Fig. 3). Les-4370 and Les-3288 were inefficient in rescuing the osteogenesis from the negative control of inflammation (Fig. 3).

In next experiments, we have shown that Les4368 and Les-3882 possessed the anti-inflammatory properties in a wide range of concentrations $(0.02$, 0.1 and $0.3 \mu \mathrm{M}$ ). The scheme of the experiment was similar to one described above. It was found that Les-4368 used in $0.02 \mu \mathrm{M}$ and $0.3 \mu \mathrm{M}$ concentra- tions and Les-3882 at all applied concentrations stimulated osteoblast differentiation comparing with a control. The best effect was found for Les-3882 that stimulated osteoblast differentiation at a low $0.1 \mu \mathrm{M}$ dose (Fig. 4).

The elucidation of the molecular mechanism of anti-inflammatory effects of Les-4368 and Les-3882. A modulation of the NF- $\kappa$ B activation by Les-3882 and Les-4368 compounds potentially could be a key mechanism mediating its anti-inflammatory effects. The $\mathrm{I} \kappa \mathrm{B} \alpha$ is a crucially important component in the control of activation of the NF- $\kappa \mathrm{B}$ pathway. Therefore, in next experiment we used the immunoblot assay with anti-IKB $\alpha$ antibodies for validation of our hypothesis based on the determination of the level of NF- $\mathrm{KB}$ signaling activation.

At the beginning we performed an experiment without use of 4-thiazolidinone compounds: $\mathrm{C} 2 \mathrm{C} 12$ cells were treated with TNF $\alpha$ for different time periods within a range of $5 \mathrm{~min}-2 \mathrm{~h}$. At the first time term (5-20 min), an expected degradation of the $\mathrm{I} \kappa \mathrm{B} \alpha$ was detected, and $30 \mathrm{~min}$ after TNF $\alpha$ treatment, de novo synthesized I $\mathrm{B} \alpha$ protein re-appears 


\section{A}

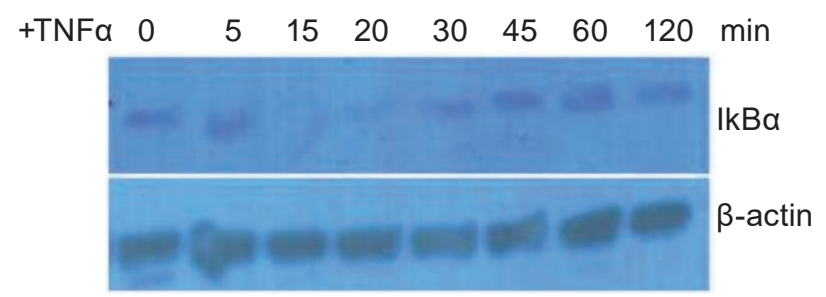

B

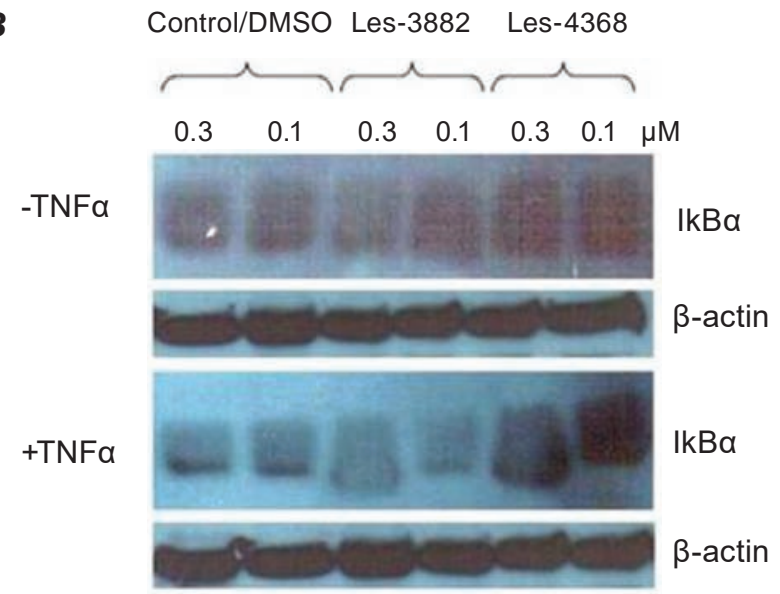

\section{C}

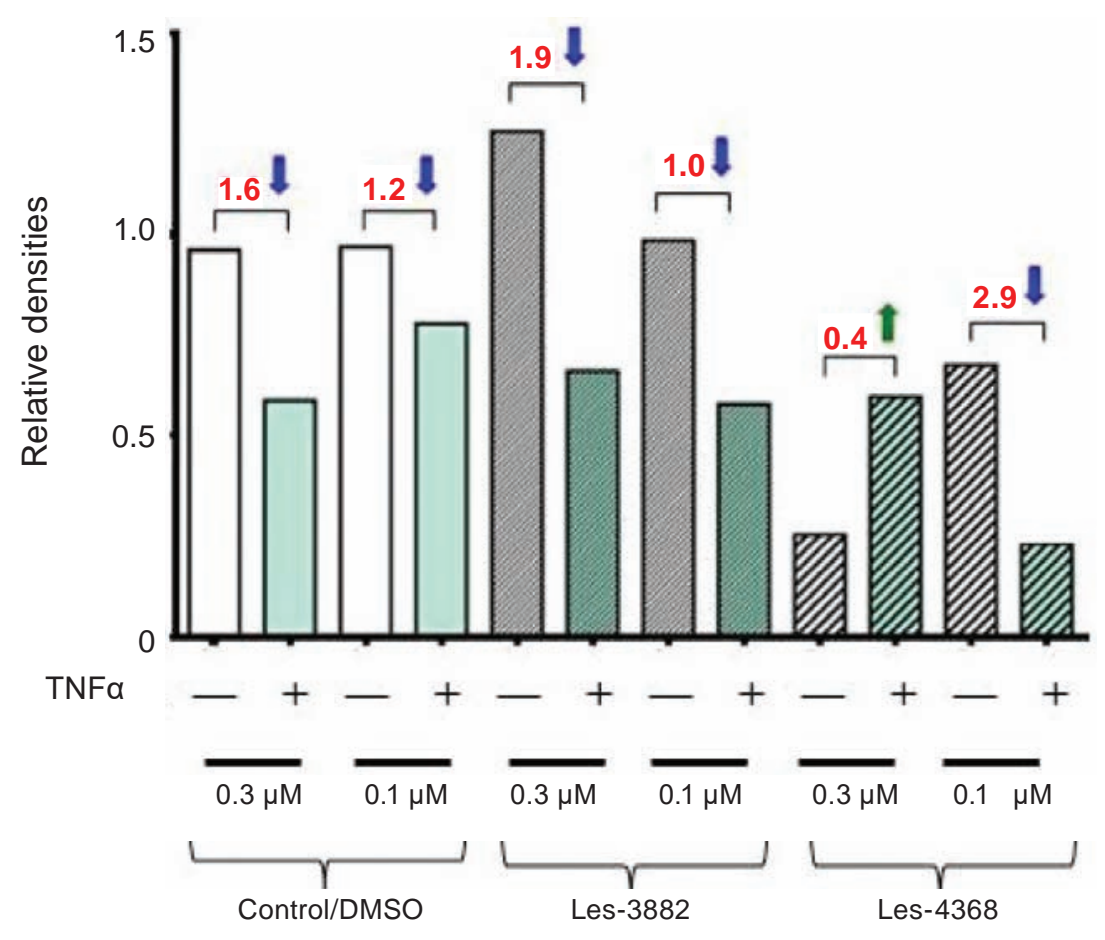

Fig. 5. Representative Western-blot assay demonstrates the effect of TNFa on the I $\mathrm{B} \alpha$ level after $5 \mathrm{~min}$ to $2 \mathrm{~h}$ incubation (A) and the effect of Les-3882 or Les-4368 at indicated concentrations on the IKBa level after $1 \mathrm{~h}$ incubation of $\mathrm{C} 2 \mathrm{C} 12$ cells with $10 \mathrm{ng} / \mathrm{ml}$ of $\mathrm{TNF} \alpha(B$ and $C)$. Densitometric quantification of the Western-blot bands is shown on panel $C$. The $\beta$-actin expression level was used as an internal control for protein loading

(Fig. 5, A). In the next experiment $\mathrm{C} 2 \mathrm{C} 12$ cells were pre-treated with Les-4368 and Les-3882 used in 0.1 and $0.3 \mu \mathrm{M}$ concentrations. TNF $\alpha(10 \mathrm{ng} / \mathrm{ml})$ was added $1 \mathrm{~h}$ after cell pretreatment with tested compounds for additional $1 \mathrm{~h}$. $\beta$-actin was used as an internal control of equal protein loading (Fig. 5B).

We found that the pretreatment of $\mathrm{C} 2 \mathrm{C} 12$ cells with Les-3882 and Les-4368 compounds with a subsequent $1 \mathrm{~h}$ stimulation with TNF $\alpha$ differently modu-

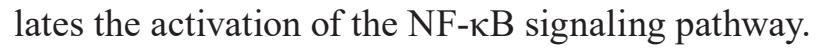
The action of Les-3882 led to a lower level of the
$\mathrm{I} \kappa \mathrm{B} \alpha$ protein after $1 \mathrm{~h}$ of the TNF $\alpha$ treatment, while Les-4368 increased the level of the I $\kappa \mathrm{B} \alpha$ protein. It is known that the NF- $\kappa \mathrm{B}$ signaling is a major pathway that mediates the effects of pro-inflammatory cytokines, and TNF $\alpha$ is one of the most potent physiological inducers of this pathway [7, 8, 25-28]. The $\mathrm{NF}-\kappa \mathrm{B}$ transcription factors consist of five compo-

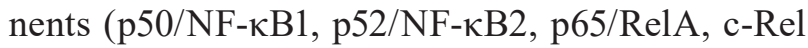
and $\mathrm{RelB}$ ) that function as dimers regulating the expression of specific target genes and participating in a regulation of a wide range of the biological pro- 
cesses. In resting cells, the NF- $\kappa \mathrm{B}$ dimers are inactivated via complex formation with the $\mathrm{I} \kappa \mathrm{B}$ proteins among which I $\kappa \mathrm{B} \alpha$ is most widely and robustly expressed. In the classical (canonical) NF- $\kappa \mathrm{B}$ signaling, binding of the TNF $\alpha$ or other ligands to their specific cell surface receptors activates an Inhibitory $\kappa \mathrm{B}$ kinase (IKK) complex consisting of the IKK $\beta$, IKK $\alpha$, and IKK $\gamma / \mathrm{NEMO}$ (NF- $\kappa \mathrm{B}$ essential modulator) that phosphorylates the I $\kappa \mathrm{B}$ proteins. Phosphorylation of the I $\kappa \mathrm{B}$ proteins triggers their ubiquitination and leads to the proteasomal destruction, thus, releasing the NF- $\kappa \mathrm{B}$ complexes. Active NF- $\kappa \mathrm{B}$ complexes are further activated by the post-translational modifications and then translocated to the nucleus where, either alone or in combination with other transcription factors, they induce target gene expression [25-28] (Fig. 6). I $\kappa \mathrm{B} \alpha$ is a direct NF- $\kappa \mathrm{B}$ target gene, and its expression is immediately induced upon the NF- $\kappa \mathrm{B}$

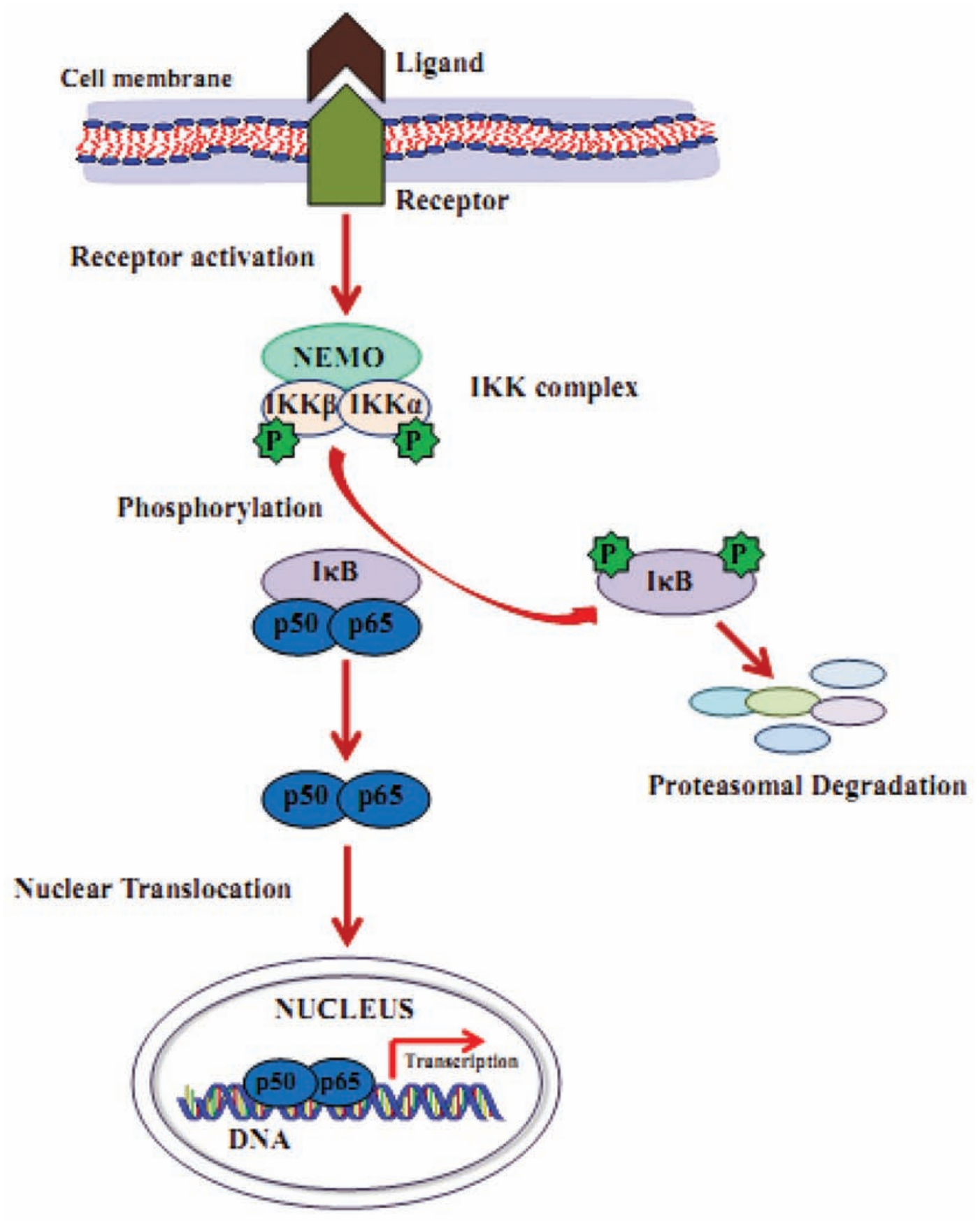

Fig. 6. Scheme of the canonical NF- $\kappa B$ signaling pathway [25-28] 
activation, thus, representing a very efficient negative feedback loop limiting maximal NF-kB activation.

In this study, we found that two 4-thiazolidinones (Les-3882 and Les-4368) demonstrated high efficiency in modulation of the anti-osteogenic effects of TNF $\alpha$ and had an opposite effect on the IкB $\alpha$ level. The explanation of such difference and more detailed mechanism of such effects requires additional study of structure-function interrelations of novel synthetic 4-thiazolodinone derivatives.

Novel 4-thiazolidinone derivatives, Les-3882 and Les-4368, rescue osteogenesis from the negative control of inflammation. The highest activity was demonstrated here by Les-3882 compound that stimulated osteoblast differentiation at a low dose $(0.1 \mu \mathrm{M})$, presumably, via modulation of the NF- $\kappa \mathrm{B}$ signaling pathway.

\section{Acknowledgment}

The study was supported by Cedars Sinai Medical Center's International Research and Innovation in Medicine Program, the Association for Regional Cooperation in the Fields of Health, Science and Technology (RECOOP HST Association) and the participating Cedars-Sinai Medical Center RECOOP Research Centers (CRRC).

\section{Financial support}

The study was partly supported by the WesternUkrainian BioMedical Research Center (WUBMRC), as well as by Grant of the Molecular \& Cellular Biotechnologies Program of the National Academy of Sciences of Ukraine (Project No 37). 


\section{ПОХІДНІ 4-ТІАЗОЛІДИНОНІВ ЗВІЛЬНЯЮТЬ ОСТЕОБЛАСТНУ ДИФЕРЕНЦІАЦІЮ ВІД НЕГАТИВНОГО ВПЛИВУ ФНПА В МЕЗЕНХІМНИХ КЛІТИНАХ- ПОПЕРЕДНИКАХ МИШ}

\author{
Х. В. Маличева $a^{1,2,3}$, Н. С. Фінюк ${ }^{1}$, \\ О. К. Павленко ${ }^{4}$, Д. Я. Гаврилюк ${ }^{5}$, \\ Р. Б. Лесик ${ }^{5}$, Р. С. Стойка ${ }^{1}$, \\ О. Г. Корчинський ${ }^{1,3}$
}

\footnotetext{
${ }^{1}$ Інститут біології клітини НАН України, Львів; ${ }^{2}$ Інститут біології тварин НААН України, Львів;

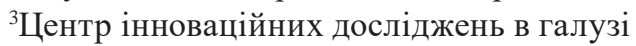
медицини та природничих наук і Медичний факультет, Жешувський університет, Польща;

${ }^{4}$ Львівський національний університет імені Івана Франко, Україна;

${ }^{5}$ Львівський медичний національний університет імені Данила Галицького, Україна; e-mail: olexkor@hotmail.com
}

Ревматоїдний артрит (РА) - це аутоімунне запальне захворювання із досі невідомою етіологією. Фактор некрозу пухлини $\alpha(Ф Н П \alpha)$ вважають регулятором, який відіграє центральну роль у виникненні і розвитку РА. 3 іншого боку, сигнальні шляхи морфогенетичних протеїнів кістки (МБК) і протеїнів Wnt $\epsilon$ ключовими механізмами, що індукують i підтримують формування хрящової і кісткової тканин. Попередні дослідження показали, що ФНП $\alpha$ та інтерлейкін $1 \beta$ відіграють головну роль в інгібуванні активності скелетогенезу. Метою даного дослідження був аналіз протизапальної активності нових 4-тіазолідінонових похідних щодо наслідків запальної реакції, опосередкованої ФНПа під час остеогенезу. Ми здійснили оцінку in vitro функціонального ефекту 4-тіазолідинонів, позначених Les-4368, Les-4370, Les-3882 і Les-3288, вжитих у різних дозах $(0,02 ; 0,1 ; 0,3$ і 1,0 мкM) на опосередковане ФНПа інгібування МБК-індукованої остеобластної диференціації мезенхімних клітин-попередників (стовбурових клітин) лінії $\mathrm{C} 2 \mathrm{C} 12$ миші. ФНП $\alpha$ повністю пригнічував їх міобластну диференціацію, а також, у значній мірі, інгібував МБК-індуковану остеобластну диференціацію. Ми встановили, що дія на клітини лінії C2C12 сполуками Les-4368 i Les3882 звільняє остеобластну диференціацію від негативного впливу ФНП $\alpha$, i, більше того, перетворює його з інгібітора остеогенезу в стимулятор. Для з'ясування механізму прозапальних ефектів досліджуваних сполук був проведений імуноблот-аналіз деградації інгібіторного $\kappa \mathrm{B} \alpha(\mathrm{I}-\kappa \mathrm{B} \alpha)$. Найкращий ефект виявила сполука Les-3882, яка підсилювала диференціацію остеобластів у низькій дозі (0,1 мкM), імовірно, шляхом модуляції сигнального шляху NF-кB.

К л ючов в с лова: остеобластна диференціація, мезенхімні клітини-попередники миші, запалення, морфогенетичні протеїни кістки, похідні 4-тіазолідинонів.

\section{ПРОИЗВОДНЫЕ 4-ТИАЗОЛИДИНОНОВ ОСВОБОЖДАЮТ ОСТЕОБЛАСТНУЮ ДИФФЕРЕНЦИАЦИЮ ОТ НЕГАТИВНОГО ВОЗДЕЙСТВИЯ ФНОА В МЕЗЕНХИМАЛЬНЫХ КЛЕТКАХ-ПРЕДШЕСТВЕННИКАХ МЫШИ}
Х. В. Малишева ${ }^{1,2,3}$, Н. С. Финюк ${ }^{1}$
А. К. Павленко ${ }^{4}$, Д. Я. Гаврылюк
Р. Б. Лесик ${ }^{5}$, Р. С. Стойка ${ }^{1}$,
А. Г. Корчинський $\check{u}^{1,3}$

${ }^{1}$ Институт биологии клетки НАН Украины, Львов; ${ }^{2}$ Институт биологии животных НААН Украины, Львов;

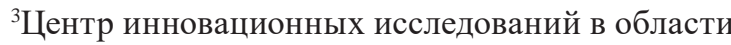
медицины и естественных наук и Медицинский факультет, Жешувский университет, Польша;

${ }^{4}$ Львовский национальный университет имени Ивана Франко, Львов, Украина;

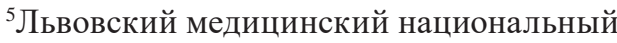
университет имени Данила Галицкого, Украина; e-mail: olexkor@hotmail.com

Ревматоидный артрит (РА) - это аутоиммунное воспалительное заболевание с еще неизвестной этиологией. Фактор некроза опухоли $\alpha$ $(\Phi H О \alpha)$ принято считать фактором регуляции, который играет центральную роль в развитии и прогрессе РА. С другой стороны, сигнальные пути морфогенетических протеинов кости (МБК) и протеинов Wnt являются ключевыми механизмами, которые индуцируют и поддерживают формирование хрящевой и костной тканей. Предыдущие исследования показали, что ФНО $\alpha$ 
и интерлейкин $1 \beta$ играют первостепенную роль в подавлении активности скелетогенних сигнальных путей. Целью данного исследования был анализ противовоспалительной активности новых 4-тиазолидинонових производных относительно последствий воспалительной реакции опосредованной $Ф Н О \alpha$ во время остеогенеза. Мы осуществили in vitro оценку функционального эффекта 4-тиазолидинонов, обозначенных Les4368 , Les-4370, Les-3882 и Les-3288) в различных дозах $(0,02 ; 0,1 ; 0,3$ и 1 мкМ) на опосредованное $\Phi Н О \alpha$ ингибирование МБК-индуцированной остеобластной дифференциации мезенхимальных клеток-предшественников (стволовых клеток) мыши линии С2C12. Как и ожидалось, $\Phi Н О \alpha$ полностью подавляет миобластную дифференциацию, а также, в значительной степени и МБК-индуцированную остеобластную дифференциацию клеток этой линии. Мы обнаружили, что обработка клеток линии С2С12 веществами Les-4368 и Les-3882, освобождает остеобластную дифференциацию от негативного влияния $\Phi Н О \alpha$ и, более того, превращает его из ингибитора остеогенеза в его стимулятор. Для выяснения механизма провоспалительных эффектов исследуемых соединений был проведен иммуноблот-анализ деградации ингибиторного $\kappa \mathrm{B} \alpha$ $\mathrm{I}-\kappa \mathrm{B} \alpha$. Лучший эффект оказало соединение Les3882 , которое в низкой дозе $(0,1$ мкМ) усиливало дифференциацию остеобластов, вероятно, путем модуляции сигнального пути NF-кB.

К л ю че вы е с лов а: остеобластная дифференциация, мезенхимальные клеткипредшественники мыши, воспаление, морфогенетические протеины кости, производные 4-тиазолидинонов.

\section{References}

1. Firestein GS. Evolving concepts of rheumatoid arthritis. Nature. 2003; 423(6937): 356-361.

2. McInnes IB, Schett G. The pathogenesis of rheumatoid arthritis. N Engl J Med. 2011; 365(23): 2205-2219.

3. Park JY, Pillinger MH. Interleukin- 6 in the pathogenesis of rheumatoid arthritis. Bull NYU Hosp Jt Dis. 2007; 65(Suppl 1): S4-10.

4. McInnes IB, Schett G. Cytokines in the pathogenesis of rheumatoid arthritis. Nat Rev Immunol. 2007; 7(6): 429-442.

5. Matsuno H, Yudoh K, Katayama R, Nakazawa F, Uzuki M, Sawai T, Yonezawa T, Saeki Y,
Panayi GS, Pitzalis C, Kimura T. The role of TNF-alpha in the pathogenesis of inflammation and joint destruction in rheumatoid arthritis (RA): a study using a human RA/SCID mouse chimera. Rheumatology (Oxford). 2002; 41(3): 329-337.

6. Jang $\mathrm{CH}$, Choi JH, Byun MS, Jue DM. Chloroquine inhibits production of TNF-alpha, IL-1beta and IL-6 from lipopolysaccharidestimulated human monocytes/macrophages by different modes. Rheumatology (Oxford). 2006; 45(6): 703-710.

7. Senftleben U, Cao Y, Xiao G, Greten FR, Krähn G, Bonizzi G, Chen Y, Hu Y, Fong A, Sun SC, Karin M. Activation by IKKalpha of a second, evolutionary conserved, NF-kappa B signaling pathway. Science. 2001; 293(5534): 1495-1499.

8. Lawrence T. The nuclear factor NF-kappaB pathway in inflammation. Cold Spring Harb Perspect Biol. 2009; 1(6): a001651.

9. Johnson ML, Kamel MA. The Wnt signaling pathway and bone metabolism. Curr Opin Rheumatol. 2007; 19(4): 376-382.

10. Issack PS, Helfet DL, Lane JM. Role of Wnt signaling in bone remodeling and repair. HSS J. 2008; 4(1): 66-70.

11. Galli C, Piemontese M, Lumetti S, Manfredi E, Macaluso GM, Passeri G. The importance of WNT pathways for bone metabolism and their regulation by implant topography. Eur Cell Mater. 2012; 24: 46-59.

12. Kwan Tat S, Padrines $M$, Théoleyre $S$, Heymann D, Fortun Y. IL-6, RANKL, TNFalpha/IL-1: interrelations in bone resorption pathophysiology. Cytokine Growth Factor Rev. 2004; 15(1): 49-60.

13. Malysheva K, de Rooij K, Lowik CW, Baeten DL, Rose-John S, Stoika R, Korchynskyi O. Interleukin 6/Wnt interactions in rheumatoid arthritis: interleukin 6 inhibits Wnt signaling in synovial fibroblasts and osteoblasts. Croat Med J. 2016;57(2): 89-98.

14. Krishnan V, Bryant HU, Macdougald OA. Regulation of bone mass by Wnt signaling. J Clin Invest. 2006; 116(5): 1202-1209.

15. Diarra D, Stolina M, Polzer K, Zwerina J, Ominsky MS, Dwyer D, Korb A, Smolen J, Hoffmann M, Scheinecker C, van der Heide D, Landewe R, Lacey D, Richards WG, Schett G. Dickkopf-1 is a master regulator of joint remodeling. Nat Med. 2007; 13(2): 156-163. 
16. Rawadi G, Roman-Roman S. Wnt signalling pathway: a new target for the treatment of osteoporosis. Expert Opin Ther Targets. 2005; 9(5): 1063-1077.

17. Gupta A, Singh R, Sonar PK, Saraf SK. Novel 4-Thiazolidinone Derivatives as Anti-Infective Agents: Synthesis, Characterization, and Antimicrobial Evaluation. Biochem Res Int. 2016; 2016: 8086762.

18. Tripathi AC, Gupta SJ, Fatima GN, Sonar PK, Verma A, Saraf SK. 4-Thiazolidinones: the advances continue... Eur J Med Chem. 2014; 72: 52-77.

19. Havrylyuk D, Zimenkovsky B, Vasylenko O, Gzella A, Lesyk R. Synthesis of new 4-thiazolidinone-, pyrazoline-, and isatin-based conjugates with promising antitumor activity. J Med Chem. 2012; 55(20): 8630-8641.

20. Senkiv J, Finiuk N, Kaminskyy D, Havrylyuk D, Wojtyra M, Kril I, Gzella A, Stoika R, Lesyk R. 5-Ene-4-thiazolidinones induce apoptosis in mammalian leukemia cells. Eur J Med Chem. 2016; 117: 33-46.

21. Havrylyuk DY, Zimenkovsky BS, Lesyk RB, Roman OM. Patent ua u201114202, Nş69857. 3-\{2-(5-(3,5-diaryl)-4,5-dihydropyrazol-1-yl)4-oxo-4h-thiazol-5-iliden\}-1,3-dihydroindol2-ones, that possess anticancer activity. Publ. 10.05.2012, Bull. No 19.

22. Korchynskyi O. Adenoviral vectors: convenient tools for gene delivery to primary mammalian cells. Biotechnologia Acta. 2012; 5(5): 16-26.
23. van der Horst $G$, van Bezooijen RL, Deckers MM, Hoogendam J, Visser A, Löwik CW, Karperien M. Differentiation of murine preosteoblastic KS483 cells depends on autocrine bone morphogenetic protein signaling during all phases of osteoblast formation. Bone. 2002; 31(6): 661-669.

24. Heffeter P, Jakupec MA, Körner W, Chiba P, Pirker C, Dornetshuber R, Elbling L, Sutterlüty H, Micksche M, Keppler BK, Berger W. Multidrugresistant cancer cells are preferential targets of the new antineoplastic lanthanum compound KP772 (FFC24). Biochem Pharmacol. 2007; 73(12): 1873-1886.

25. DiDonato JA, Mercurio F, Karin M. NF- $k B$ and the link between inflammation and cancer. Immunol Rev. 2012; 246(1): 379-400.

26. Mitchell S, Vargas J, Hoffmann A. Signaling via the NFkB system. Wiley Interdiscip Rev Syst Biol Med. 2016; 8(3): 227-241.

27. Hoffmann A, Baltimore D. Circuitry of nuclear factor kappaB signaling. Immunol Rev. 2006; 210: 171-186.

28. Rinkenbaugh AL, Baldwin AS. The NF- $\kappa B$ Pathway and Cancer Stem Cells. Cells. 2016; 5(2). pii: E16.

Received 31.01.2017 